\title{
Algal Communities Associated with Different Alpine Stream Types*
}

\author{
Mäggi Hieber, ${ }^{1}$ \\ Christopher T. Robinson, ${ }^{1}$ \\ Samuel R. Rushforth, ${ }^{2}$ \\ and Urs Uehlinger ${ }^{1}$ \\ ${ }^{1}$ Department of Limnology, EAWAG/ \\ ETH, Überlandstrasse 133, CH-8600 \\ Dübendorf, Switzerland. \\ hieber@eawag.ch \\ ${ }^{2}$ Department of Botany and Range \\ Sciences, Brigham Young University, \\ Provo, Utah 84602, U.S.A. Present \\ address: School of Science and \\ Health, Utah Valley State College, \\ Orem, Utah 84058, U.S.A.
}

\begin{abstract}
We investigated major physical-chemical characteristics and benthic algae of different alpine lotic systems comprising streams and lake outlets of rhithral and kryal origin over an annual cycle. We also evaluated the structure of the algal communities and its relation to environmental characteristics for the different stream types. Algal communities were generally dominated by diatoms, Cyanophyta, and Hydrurus foetidus (Chrysophyceae). Community structure was similar among alpine streams and lake outlets, but more algal taxa occurred in lake outlets (rhithral and kryal) than in kryal streams. Although algae were identified mainly to genera, distinct patterns in community structure were evident. A major environmental determinant of the algal community among stream types was the presence of a glacier and resulting seasonal differences in flow, temperature, and turbidity. An upstream lake was a secondary determinant in buffering seasonal fluctuations in environmental conditions thus leading to greater stability. Algal communities, consequently, were more diverse and less seasonally variable at lake outlets. The diatom genera Amphora, Denticula, Fragilaria, Gomphonema, Nitzschia, and Synedra and the blue-green algae Oscillatoria and Phormidium were characteristic of lake outlets, whereas Chamaesiphon (blue-green) and Hydrurus foetidus were indicative of kryal sites.
\end{abstract}

\section{Introduction}

Alpine lotic systems generally are characterized by cold temperature (low number of annual degree days), turbulent welloxygenated water, and high discharge fluctuations. These systems, however, comprise a diversity of stream types. Ward (1994) distinguished high-altitude headwaters as kryal, rhithral, or krenal depending on their primary water source. Kryal streams are primarily fed by glacial meltwater and have low water temperature $\left(<4^{\circ} \mathrm{C}\right)$, high turbidity during snow and ice melt ( $>30 \mathrm{NTU}$ ), and a seasonal and diel fluctuating flow regime that causes unstable channel beds and variable habitat conditions (Milner and Petts, 1994; Ward, 1994). Rhithral streams are mainly fed by snowmelt and have lower diel variations in discharge, whereas krenal streams are groundwater fed and represent a stable habitat throughout the year.

Another stream type, almost neglected so far, are lake outlets of kryal or rhithral origin. Lowland lake outlets typically show a more stable temperature and discharge regime (Malmqvist and Brönmark, 1984), a relatively stable, single-thread channel (Milner and Petts, 1994), and higher concentrations of transported organic material (Brönmark and Malmqvist, 1984) than respective nonoutlet streams. In alpine regions, an upstream lake is expected to increase water temperature and attenuate floods thus leading to a more stable channel (Milner and Petts, 1994); however, little information is available at present.

Environmental conditions can influence the algal diversity of lotic systems by constraining particular species. Several studies have related periphyton communities and their species traits with different habitat parameters such as water velocity (Maier,

*A version of this paper was presented at the Symposium "Highmountain Lakes and Streams," 4-8 September 2000, Innsbruck, Austria.
1994; Biggs et al., 1998), disturbance (Kuhn et al., 1981; Grimm and Fisher, 1989), water temperature (Kann, 1978), substratum (Maier, 1994; Cattaneo et al., 1997), water chemistry (Kann, 1978; Passy et al., 1999), and nutrient supply (Kuhn et al., 1981; Passy et al., 1999). These relationships have led to the use of periphyton as an ecological indicator in river assessment (see citations in Round, 1993; Hill et al., 2000). The successful use of periphyton to assess water quality has been based on different taxonomic levels and functional groups (Round, 1993; Steneck and Dethier, 1994; Chessman et al., 1999).

Numerous studies on algal communities have been conducted in mid- and lowland streams, whereas little data exist for alpine and glacial streams. Studies of glacial streams are mainly from arctic and antarctic regions that belong to a different biogeographical zone (Elster and Svoboda, 1996; Alger et al., 1997). Further, the few studies of high-mountain lotic freshwaters were completed mostly on streams without an upstream lake (Brun, 1965; Kawecka, 1980, 1981; Maier, 1994; Uehlinger et al., 1998; Passy et al., 1999; Vavilova and Lewis, 1999), with little data from high-mountain lake outlets (Kawecka, 1965, 1980; Kann, 1978).

We investigated habitat characteristics and associated algal communities of different alpine stream systems that comprised rhithral and kryal streams and respective lake outlets. We expected the glacial influence on kryal systems to have a strong affect on algal community structure, although this influence may be mitigated in kryal lake outlets. In addition, we examined for seasonal and longitudinal patterns in algal community structure among the different alpine streams.

\section{Study Sites}

Study sites were situated in the Swiss Alps above treeline at elevations ranging from 1900 to $2500 \mathrm{~m}$ a.s.l.; only the kryal 


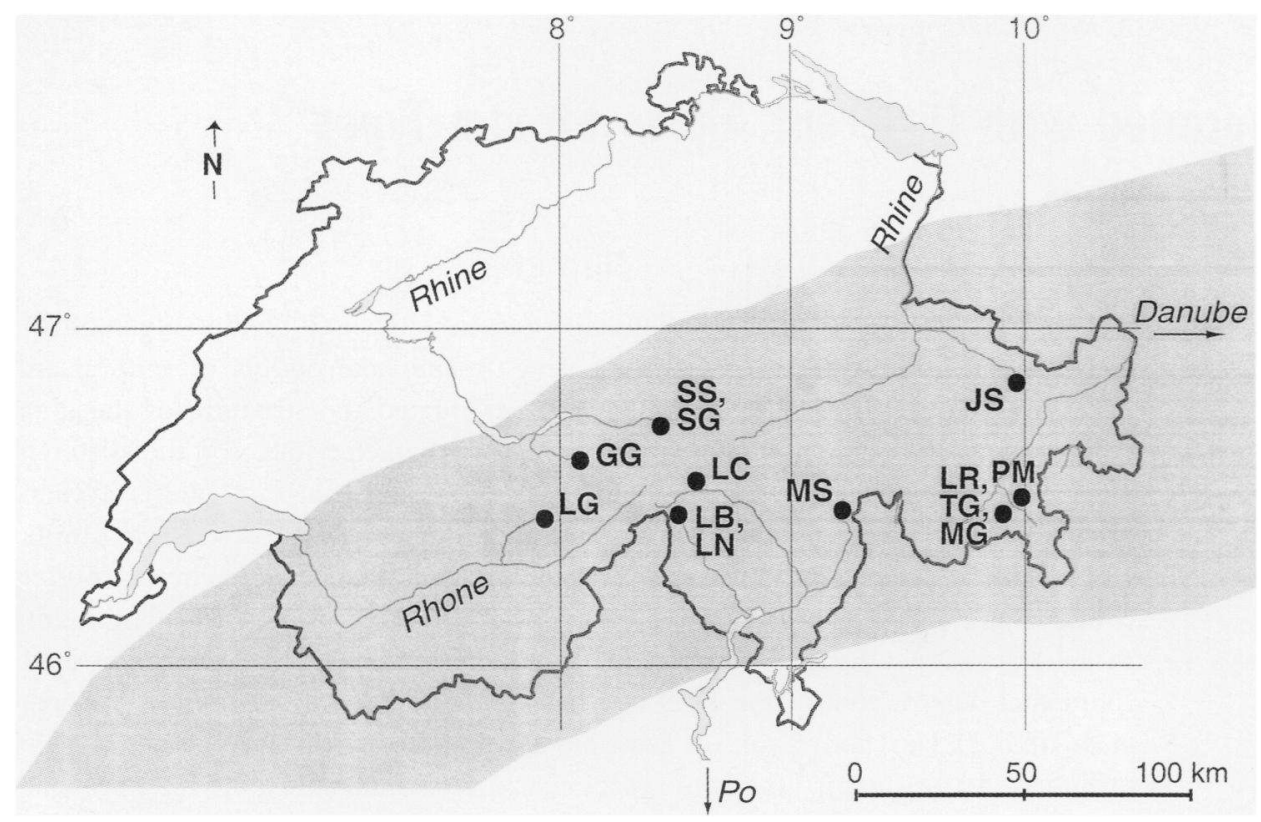

FIGURE 1. Map of Switzerland with locations of the study sites in the Swiss Alps (shaded region). River names indicate the major drainages where respective study sites originate. Site notations defined in Table 1. stream Grindelwald was below treeline at $1200 \mathrm{~m}$ a.s.l. (Fig. 1). Sites consisted of alpine lake outlets and streams of kryal and rhithral origin from the four major drainage areas (Po, Danube, Rhine, and Rhone) in Switzerland (Table 1). Catchment size ranged from 0.8 to $35 \mathrm{~km}^{2}$ with kryal sites in the largest catchments and rhithral sites in catchments $<4 \mathrm{~km}^{2}$. Stream slope ranged from 1.3 to $16 \%$, being higher at stream sites than lake outlets. In the following text, the term "stream type" comprises (1) "streams"- -without an upstream lake, and (2) "lake outlets."

Three glacial-fed streams (Morteratsch, Grindelwald, and Lang) were sampled at two sites, one close to the glacier mouth and the other ca. 300 to $500 \mathrm{~m}$ downstream. Only one rhithral stream was sampled, this being from June to October 1999. The outlet of the Joerisee is rhithral, but is influenced by the Joeriglacier that flows into a small lake above the Joerisee.

Observations of changes in channel morphology (e.g., lateral channel shift) over the study period indicated that rhithral sites were more physically stable than kryal sites. Among the kryal sites, Morteratsch and Steinlimi represented the more stable streams and the outlet of Lej Roseg appeared more stable than the outlet of the Steinsee where substantial erosion of the ancient end moraine of the Steinglacier occurred. All sites are in the crystalline area of the Swiss Alps with bedrock mainly consisting of granite and gneiss. The catchments are covered mostly by rocks, with sparse vegetation of grass and low shrubs of alder (Alnus sp.) and willow (Salix sp.) also present.

\section{Methods}

\section{PHYSICAL AND CHEMICAL MEASURES}

On each sampling date, specific conductance (WTW model 325) and turbidity (Cosmos Züllig, in nephelometric turbidity units; NTUs) were measured in the field. A water sample (1 L) was collected, filtered through pre-ashed glass fiber filters (Whatman GF/F filters; $45 \mathrm{~mm}$ diameter) and analyzed for the following chemical parameters in the laboratory: ammonium $\left(\mathrm{NH}_{4}\right)$, nitrate $\left(\mathrm{NO}_{3}\right)$, nitrite $\left(\mathrm{NO}_{2}\right)$, dissolved (DN) and particulate nitrogen ( $\mathrm{PN})$, soluble reactive phosphorus (SRP), total dissolved (DP) and particulate phosphorus (PP), dissolved (DOC) and particulate organic carbon (POC), total suspended solids (TSS) and ash-free dry mass (AFDM). Determination of each parameter followed the methods described in detail in Tockner et al. (1997). At each site, water temperature was recorded hourly with temperature loggers (Minilog, Vemco). Two-way analysis of covariance (ANCOVA) was used to compare among rhithral vs. kryal sites and streams vs. lake outlets, with date as the covariate (Zar, 1984).

\section{ALGAL COMMUNITIES}

At 16 sites, algal samples were collected seasonally three to six times between July 1998 and October 1999 depending on site accessibility. On each date, we collected 10 stones per site ( $b$ axis $=2.8-14.0 \mathrm{~cm}$, median $=7.0 \mathrm{~cm})$ from predominant instream habitats. The stones were stored at minus $25^{\circ} \mathrm{C}$ until processed in the laboratory. For algal identification, periphyton was removed from each stone by brushing with a metal bristle brush. The algal suspension from each group of 10 stones per site and date was composited, an aliquot of 20 to $25 \mathrm{ml}$ was removed and preserved in $2 \%$ formalin for later identification and enumeration. Individual subsamples were placed on glass microscope slides and examined directly for the general abundance of algal taxa as classified according to the Index of Relative Species Abundance (Elster and Svoboda, 1996) (Table 2). In general, if a taxon was represented by only one or a few specimens it was recorded as rare and assigned a value of 1 . If a taxon was present in around 5 to $10 \%$ of the microscopic examination fields it was recorded as common (value $=3$ ). If a taxon was present in $>20 \%$ of the examination fields it was recorded as abundant and given a value of 5 .

Algal taxa from all samples were identified mainly at $400 \times$ (maximum $1000 \times$ ) to genus level. Stream samples were examined using a Zeiss IM microscope, and samples from the lake outlets using a Zeiss RA microscope with Normarski and brightfield optics. In addition, lake outlet samples were examined for identification of diatom species as little data from high-mountain lake outlets exist. Each sample was boiled in concentrated nitric acid, rinsed, mounted in Naphrax mountant, and examined at $1000 \times$ oil immersion using a Zeiss RA microscope with Nomarski optics. Counts of 450 to 650 diatom cells were made 
TABLE 1

Location and general characteristics of the study sites ${ }^{\mathrm{a}}$

\begin{tabular}{|c|c|c|c|c|c|c|c|c|c|}
\hline Site & Notation & Origin & Lotic type & Drainage & $\begin{array}{l}\text { Elevation } \\
\text { (m a.s.1.) }\end{array}$ & $\begin{array}{c}\text { Catchment } \\
\left(\mathrm{km}^{2}\right)\end{array}$ & Slope (\%) & $\begin{array}{l}\text { Temperature } \\
\text { range }\left({ }^{\circ} \mathrm{C}\right)\end{array}$ & $\begin{array}{c}\text { Turbidity range } \\
\text { (NTU) }\end{array}$ \\
\hline Lago Bianco & LB & $\mathbf{r}$ & $\mathrm{L}$ & Po & 2076 & 2.1 & 4 & $0.0-15.3$ & $0.3-2.9$ \\
\hline Lago Cadagno & LC & $\mathbf{r}$ & $\mathrm{L}$ & Po & 1923 & 2.2 & 3 & NA & $1.2-2.5$ \\
\hline Lago Nero & LN & $\mathbf{r}$ & $\mathrm{L}$ & Po & 2387 & 0.8 & 5 & $0.0-16.3$ & $0.2-1.4$ \\
\hline Puoz Minor & PM & $\mathbf{r}$ & $\mathrm{L}$ & Danube & 2336 & 1.8 & 9 & $0.0-16.0$ & $0.7-5.6$ \\
\hline Jörisee & JS & $\mathrm{r}(\mathrm{k})$ & $\mathrm{L}$ & Rhine & 2489 & 3.4 & 5 & $0.1-16.2$ & $3.9-67$ \\
\hline Steinsee & SS & $\mathrm{k}$ & $\mathrm{L}$ & Rhine & 1934 & 7.3 & 4 & $1.6-4.2$ & $57-126$ \\
\hline Lej Roseg & LR & $\mathrm{k}$ & $\mathrm{L}$ & Danube & 2159 & 19.3 & 2 & $0.0-9.1$ & $47-361$ \\
\hline Moesa & MS & $\mathbf{r}$ & $S$ & Po & 2300 & 0.6 & 16 & $0.8-12.0$ & $0.1-3.2$ \\
\hline Tschierva & TG & $\mathrm{k}$ & $\mathrm{S}$ & Danube & 2100 & 14.7 & 4 & $0.1-4.0$ & $31-3284$ \\
\hline \multicolumn{10}{|l|}{ Morteratsch } \\
\hline -upstream & MG1 & $\mathrm{k}$ & $\mathrm{S}$ & Danube & 2000 & 35.0 & 1 & $0.0-3.2$ & $1-722$ \\
\hline -downstream & MG2 & & & & 1970 & 35.5 & 5 & & $4-676$ \\
\hline Steinlimi & SG & $\mathrm{k}$ & $\mathrm{S}$ & Rhine & 2090 & 3.4 & 2 & $0.1-3.9$ & $14-109$ \\
\hline \multicolumn{10}{|l|}{ Grindelwald } \\
\hline -upstream & GG1 & $\mathrm{k}$ & $\mathrm{S}$ & Rhine & 1240 & 17.3 & 8 & $0.0-2.8$ & $1-286$ \\
\hline -downstream & GG2 & & & & 1210 & 17.5 & 6 & & $0.4-373$ \\
\hline \multicolumn{10}{|l|}{ Lang } \\
\hline -upstream & LG1 & $\mathrm{k}$ & $\mathrm{S}$ & Rhone & 1990 & 18.6 & 8 & $0.0-2.7$ & $17-171$ \\
\hline -downstream & LG2 & & & & 1910 & 29.3 & 6 & & $75-171$ \\
\hline
\end{tabular}

${ }^{a}$ Ranges are listed as minimum-maximum. $\mathrm{k}=\mathrm{kryal}, \mathrm{r}=$ rhithral, $\mathrm{L}=$ lake outlet, $\mathrm{S}=$ stream, NTU: nephelometric turbidity units. NA: not available.

from each slide to identify diatoms and estimate relative densities. To standardize the analysis of the two data sets (genera for streams, species for lake outlets), the absolute algal numbers of lake outlets were summarized by genera and then transformed $0.5 * \log _{2}$ to categorize each taxon as used to describe the abundance patterns for genera as above (Table 2).

Thus, algal samples were analyzed in two ways: (1) algae of all sites were examined at the genus level based on categories; and (2) diatoms of the lake outlet samples were analyzed based on species level as relative densities from the absolute counts. In the remaining text, the term "genus" refers to the first analysis based on categorical data even though some taxa are listed as species (e.g., Hydrurus foetidus, Hannaea arcus). The term "species," in contrast, refers to the second analysis based on diatom species of lake outlets.

For the categorical data, differences among study sites were analyzed using ANCOVA with date as the covariate (Zar, 1984). One-way ANCOVA was used to compare among individual sites, whereas two-way ANCOVA was used to compare lake outlet vs. stream and kryal vs. rhithral types. If differences were detected by ANCOVA, the Tukey HSD test was used to determine which types actually differed (Zar, 1984). To compare among types, both upstream and downstream sites were included in the type "kryal stream." We also used indirect PCA to illustrate the differences in community structure among sites in re-

TABLE 2

Classification of algal taxa by relative abundance after transformation of the absolute numbers by $0.5 * \log _{2}$

\begin{tabular}{ccl}
\hline \hline Class & Abundance & $\begin{array}{c}\text { Corresponding } \\
\text { visual occurrence }\end{array}$ \\
\hline 1 & $0-7$ & rare \\
2 & $8-31$ & rare-common \\
3 & $32-131$ & common \\
4 & $132-527$ & common-abundant \\
5 & $<528$ & abundant \\
\hline
\end{tabular}

lation to environmental variables. Indirect gradient analysis orders samples from biotic data only, and environmental variables are subsequently used to interpret the biotic ordination; PCA was used as genera displayed a linear response (gradient length $<4$ SD) (ter Braak and Smilauer, 1998). PCA was based on the frequency (categorical data) of algal genera comprising $>1 \%$ of the algal community and environmental variables for each site and date (data log-transformed and centered by taxa). Ordination analysis was performed with Canoco 4 (ter Braak and Smilauer, 1998).

\section{Results}

\section{PHYSICAL AND CHEMICAL CHARACTERISTICS}

Kryal and rhithral sites, as well as lake outlet and stream sites, differed primarily in maximum water temperature and turbidity (Table 1). Temperature at rhithral sites reached almost $17^{\circ} \mathrm{C}$ compared to $<10^{\circ} \mathrm{C}$ at kryal sites. Temperatures of kryal streams never exceeded $4^{\circ} \mathrm{C}$, whereas it reached $9.1^{\circ} \mathrm{C}$ in the kryal outlet of the Lej Roseg. Kryal stream types had high turbidity, reaching $>3000$ NTU (site TG) during glacial melt in summer. Kryal lake outlets were less turbid relative to kryal streams, but still had higher values than rhithral sites (turbidity typically was $<10$ NTU). As an exception, Joerisee outlet reached 67 NTU during summer reflecting the influence of the adjacent glacier.

Mean specific conductance varied between 13 and $135 \mu \mathrm{S}$ $\mathrm{cm}^{-1}$, with no significant differences among types $(P=0.33)$. Mean nutrient concentrations ranged from 1 to $33 \mu \mathrm{g} \mathrm{NH}_{4} \mathrm{~L}^{-1}$, 20 to $358 \mu \mathrm{g} \mathrm{NO} \mathrm{NO}_{2}+\mathrm{NO}_{3} \mathrm{~L}^{-1}, 121$ to $414 \mu \mathrm{g} \mathrm{DN} \mathrm{L}-1,8$ to 70 $\mu \mathrm{g}$ PN L ${ }^{-1}, 0$ to $3.7 \mu \mathrm{g} \mathrm{SRP} \mathrm{L}^{-1}, 0.3$ to $5.8 \mu \mathrm{g} \mathrm{DP} \mathrm{L}^{-1}, 1$ to $112 \mu \mathrm{g} \mathrm{PP} \mathrm{L}^{-1}, 0.3$ to $1.4 \mathrm{mg}$ DOC L $\mathrm{L}^{-1}, 0.1$ to $2.0 \mathrm{mg} \mathrm{POC} \mathrm{L}^{-1}$, 0.1 to $150 \mathrm{mg} \mathrm{TSS} \mathrm{L}^{-1}$, and 0.8 to $4.3 \mathrm{mg} \mathrm{AFDM} \mathrm{L}^{-1}$. Concentrations of $\mathrm{NH}_{4}, \mathrm{NO}_{2}+\mathrm{NO}_{3}, \mathrm{PP}$, and TSS were significantly higher at kryal sites than at rhithral sites $(P<0.03)$. Differences between lake outlet and stream sites were significant only for nitrogen parameters $\left(\mathrm{NO}_{2}+\mathrm{NO}_{3}, \mathrm{DN}, \mathrm{PN} ; P<0.05\right)$, these being 


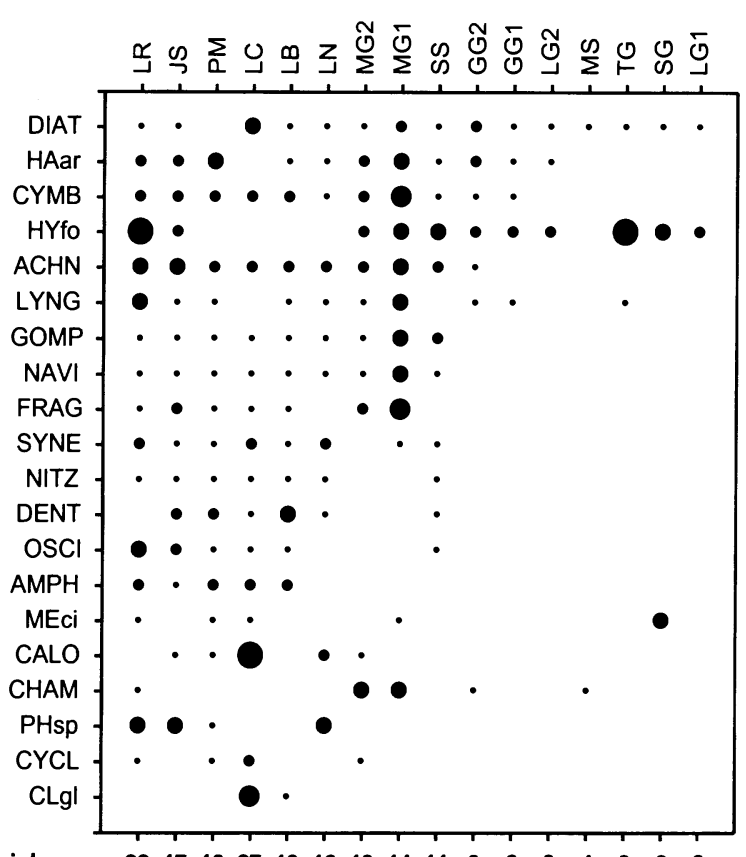

$\begin{array}{llllllllllllllllll}\text { genus richness } & 22 & 17 & 18 & 27 & 19 & 16 & 13 & 14 & 11 & 8 & 6 & 3 & 4 & 3 & 2 & 2\end{array}$

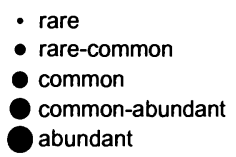

FIGURE 2. Average abundance of algal genera having a total frequency $>1 \%$, and total genus richness for each site. Sites (notations as defined in Table 1) and algal genera (notations as defined in Appendix 1) are ordered by decreasing genus richness, and by decreasing number of sites a genus was present.

higher in stream sites. Longitudinally, kryal streams showed no significant differences in their physical and chemical characteristics $(P=0.75)$.

Seasonal patterns in physical-chemical measures occurred only at kryal sites. Specific conductance was highest in kryal sites during late autumn/winter when discharge was low, whereas turbidity, $\mathrm{PP}$ and $\mathrm{NH}_{4}$ were highest during summer when discharge was high from melting snow and glacial ice.

\section{ALGAL COMMUNITY STRUCTURE AMONG STREAM TYPES}

A total of 42 genera was identified. The majority belonged to the Cyanophyta (blue-green algae), Chrysophyceae (gold algae), Bacillariophyceae (diatoms), and Chlorophyta (green algae), whereas Pyrrophyta (fire algae) and Rhodophyta (red algae) were represented by only one species occurring sporadically (Appendix 1). Abundant genera included the pennate diatoms Achnanthes spp., Cymbella spp., Diatoma spp., Gomphonema spp., and Hannaea arcus, Lyngbya spp. (Cyanophyta), and Hydrurus foetidus (Chrysophyceae).

Kryal and rhithral lake outlets had more genera than streams $(P<0.001)$. Genus richness of lake outlets varied between 16 to 27, whereas streams (kryal and rhithral) typically had more than 10 genera (except Morteratsch) (Fig. 2). One glacial lake outlet (site SS) had only 11 algae genera, and thus was similar to kryal streams. Genus richness of kryal lake outlets also differed from rhithral lake outlets $(P<0.001)$, as did richness of kryal and rhithral sites $(P=0.03)$. However, kryal and rhithral streams showed no differences in genus richness $(P=$
0.88 ), but only one rhithral stream was sampled. Kryal streams showed no longitudinal patterns in their genus richness. For example, genus richness increased at Lang and Grindelwald downstream but decreased by one taxon at Morteratsch (Fig. 2).

Representatives of the algal genera Achnanthes, Cymbella, Diatoma, Hannaea, Meridion, Navicula (Bacillariophyceae), and Lyngbya (Cyanophyta) were present in all stream types except the rhithral stream (Fig. 2). Hydrurus foetidus (Chrysophyceae) occurred only at kryal sites and the Joerisee where it often dominated the algal community. Microspora (Chlorophyta) and Chamaesiphon (Cyanophyta) also were found primarily at kryal sites. Algal genera that occurred only at lake outlets included lentic as well as lotic forms such as Amphora, Cocconeis, Denticula, Epithemia, Eunotia, Nitzschia, Pinnularia (Bacillariophyceae), Cladophora glomerata (Chlorophyta), Chroococcus, Oscillatoria and Phormidium (Cyanophyta), and Audouinella violacea (Rhodophyta) (Fig. 2). Mean occurrence for most genera was low; only Cymbella, Hydrurus foetidus, Fragilaria, Calothrix, and Cladophora occurred at one or two sites with high average frequency (category class $=4$ or 5 ).

\section{DIATOM SPECIES OF LAKE OUTLETS}

The most diatom species were found in the outlet of Lago Cadagno (46 species), 38 species occurred in the kryal Lej Roseg outlet, and 36 diatom species in the rhithral Lago Bianco and Puoz Minor outlets. The lowest number of diatom species occurred in the Steinsee outlet (20) and the rhithral Lago Nero (23) and the Jörisee (23) outlets (Appendix 1). Achnanthes minutissima dominated (13 to $99 \%$ ) the diatom community at all outlets. Other frequent species were Cymbella minuta, Hannaea arcus, Synedra delicatissima, and $S$. rumpens. In addition to these, diatom communities of kryal lake outlets were dominated by Gomphonema olivaceum, whereas Amphora perpusilla, Cymbella affinis, and Denticula elegans occurred mainly at rhithral lake outlets. Average species composition was similar between rhithral and kryal lake outlets, but more rare species were identified from rhithral lake outlets.

\section{SEASONALITY IN ALGAL COMMUNITY STRUCTURE}

Algal genus richness was quite constant during the study period at the rhithral lake outlets. At kryal sites, algal communities had low genus richness during summer and higher richness during late autumn/winter; however, seasonality was most pronounced at kryal lake outlets (Fig. 3). The sampling period in the rhithral stream included only $4 \mathrm{mo}$, thus seasonal patterns are not discussed.

Most algal taxa showed seasonal differences in abundance at most sites. An analysis of the average frequency of the top five taxa from each site showed generally high abundances in autumn/winter (Fig. 4). Figure 4a shows the top five genera of each stream site with four or more sampling dates. Most genera had maximum or high abundance in autumn/winter (e.g., Hannaea arcus, Hydrurus foetidus, Fragilaria spp.) and were present for only a short time (e.g., Achnanthes spp., Diatoma spp.). Only a few genera occurred at high frequencies during spring and summer, whereas most genera were absent or occurred only in low abundances.

An analysis of the average frequency of the top five species for lake outlets ( $\geq 3$ sampling dates) showed similar seasonal patterns (Fig. 4b). Seasonal patterns were most distinct at sites with kryal influence (Joerisee, Lej Roseg, Steinsee) and the rhithral Lago Nero outlet. Most species had maximum abun- 

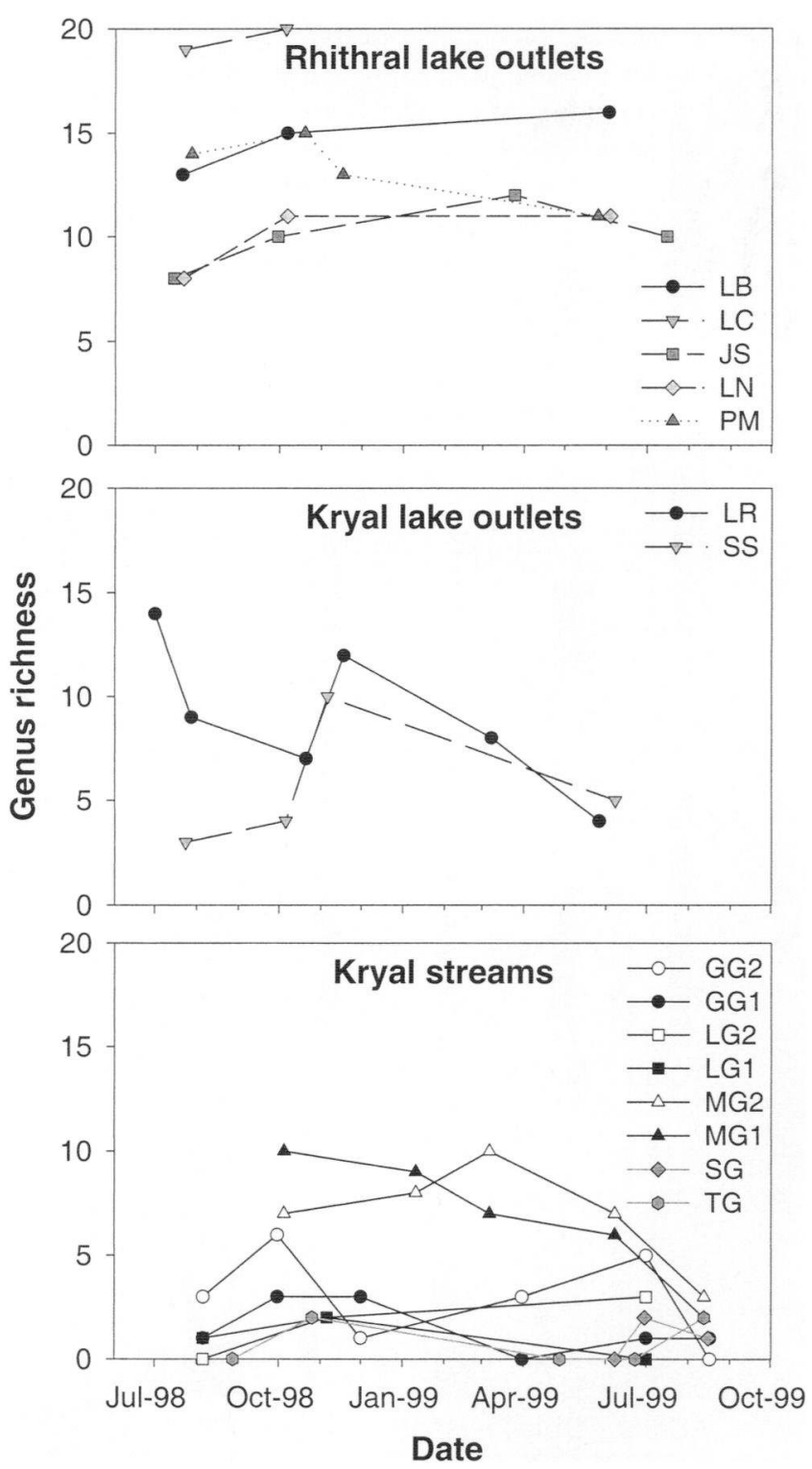

FIGURE 3. Seasonal changes in total genus richness at all lake outlet and kryal stream sites. Kryal streams with two sampling sites are indicated by the same symbol: open $=$ downstream, filled $=$ upstream.

dances in autumn and winter with many being absent during spring and summer (e.g., Phormidium, Denticula tenuis, Syne$d r a$, and Nitzschia species). Species abundance at the rhithral lake outlets seemed more constant over the year maintaining high abundances in summer. Achnanthes minutissima occurred at all lake outlet sites in high abundance throughout the study period with no seasonality.

\section{ALGAL AND ENVIRONMENTAL RELATIONSHIPS}

PCA ordination, combining algal and environmental data, clearly separated streams from lake outlets (Fig. 5). Lake outlets were mainly grouped by Achnanthes, Cymbella, Synedra, and Gomphonema (Fig. 5a). Rhithral lake outlets were grouped together, whereas kryal lake outlets were more widely distributed resulting from seasonality in algal composition. Seasonality also was evident at the glacier-influenced Jörisee outlet, with summer samples near kryal lake outlets and spring/autumn samples near rhithral sites. Stream sites were widely distributed and mainly distinguished by nondiatom genera Hydrurus foetidus, Lyngbya spp., and Chamaesiphon spp. (Fig. 5b). Kryal streams with low genus richness (Lang, Steinlimi, Tschierva) were grouped by $\mathrm{Hy}$ drurus foetidus with no differences among dates. Two kryal streams with high richness (Grindelwald, Morteratsch), however, showed high variability related to seasonal changes in community structure and the presence or absence of a single genus (e.g., Achnanthes, Diatoma, Hydrurus foetidus). The rhithral stream had low genus richness and overall low abundances.

Distribution of each sampling date per site based on environmental data followed patterns described above, separating rhithral and kryal sites mainly on the first axis that explained $36.1 \%$ of the total species-environment relation (Fig. 5c). Rhithral sites were distinguished by higher maximum water temperature, DOC, DP, and PN, and kryal sites by higher concentrations of TSS, turbidity, and PP.

\section{Discussion}

\section{ALGAL COMMUNITY STRUCTURE}

Algal communities of the studied alpine lotic systems generally had a similar structure among streams and lake outlets, being dominated by diatoms, blue-green algae, and the Chrysophyceae Hydrurus foetidus. These have been found to be dominant taxa in other alpine streams of middle-latitude mountains of the northern hemisphere (e.g., Kawecka, 1980; Vavilova and Lewis, 1999). Kryal streams were characterized by a low number of genera and the dominance of Hydrurus foetidus, which is the predominant taxon in alpine kryal streams (Kawecka, 1980; Uehlinger et al., 1998) but also common in other alpine streams and lake outlets (Kann, 1978; Vavilova and Lewis, 1999). Hydrurus foetidus is a widely distributed stenothermic cold-water algae that can resist strong current by forming a gelatinous cover on the substrate (Kawecka, 1981; Rott et al., 1999). The most frequent blue-green algae in our study sites were the genera Chamaesiphon and Lyngbya in kryal streams and Oscillatoria and Phormidium in rhithral and kryal lake outlets. Distinct species of Chamaesiphon (e.g., C. fuscus, C. incrustans, C. polonicus) are common in alpine streams and lake outlets, being able to resist winter freezing and summer drought by forming crusts (Kann, 1978; Kawecka, 1980). Representatives of Lyngbya, Oscillatoria, and Phormidium were dominant taxa in studies of other alpine lake outlets (Kann, 1978; Kawecka, 1980). Many species of these three genera are typically either free-living or filamentous loosely aggregated forms and are common in standing and slow-flowing waters (Geitler, 1971; Rott et al., 1999).

Diatom genera common to most of our study sites included Achnanthes spp., Cymbella spp., Diatoma spp., Gomphonema spp., Hannaea arcus, Meridion circulare, and Navicula spp.; taxa widely distributed in all kinds of freshwaters (Brun, 1965; Kawecka, 1980). Diatoms occurring at kryal sites generally were nonmotile with strong attachment abilities that can resist high discharge and abrasion by glacial flour, belonging to the socalled pioneer species with high resilience (e.g., Achnanthes spp., Diatoma spp., Fragilaria spp., Hannaea arcus). Diatoms occurring only in rhithral lake outlets belonged to motile and free-living forms (e.g., Amphora spp., Oscillatoria spp.) and filamentous, loosely aggregated forms (e.g., Navicula spp.). Due to the small sample size, no statement on algal community composition of rhithral streams can be made from our study. Kawecka (1980), however, described the benthic algae of different rhithral streams of European mountains as species rich com- 
a)
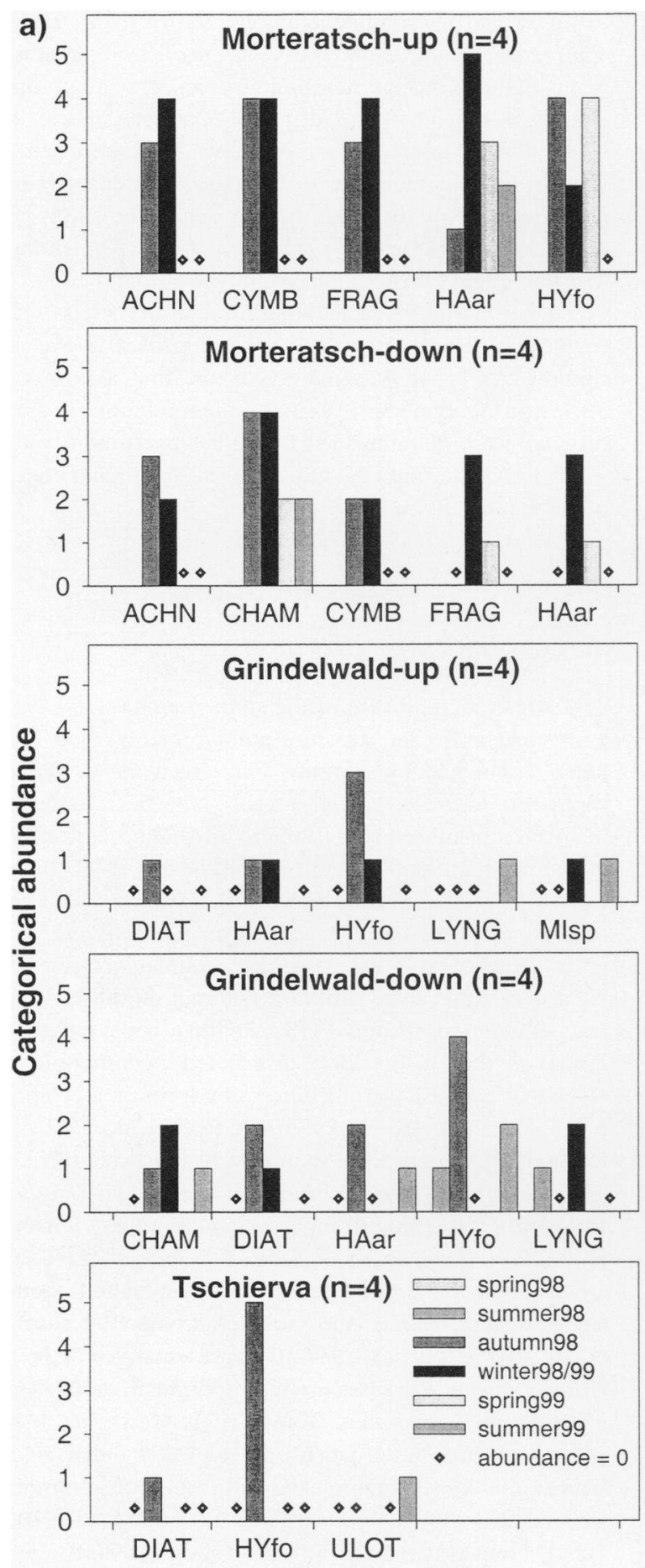
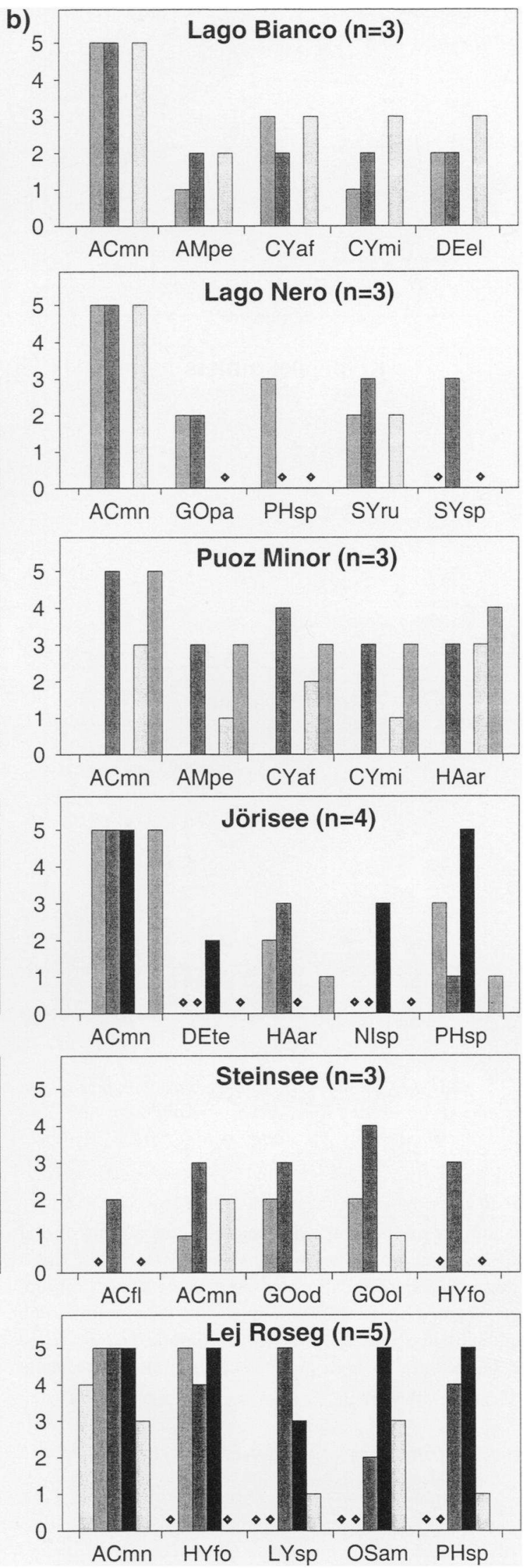

FIGURE 4. Abundance of the top five algal taxa; a) based on genus level for stream sites, and b) based on species level for lake outlet sites. $n=$ sampling dates. Algal notations defined in Appendix 1. 


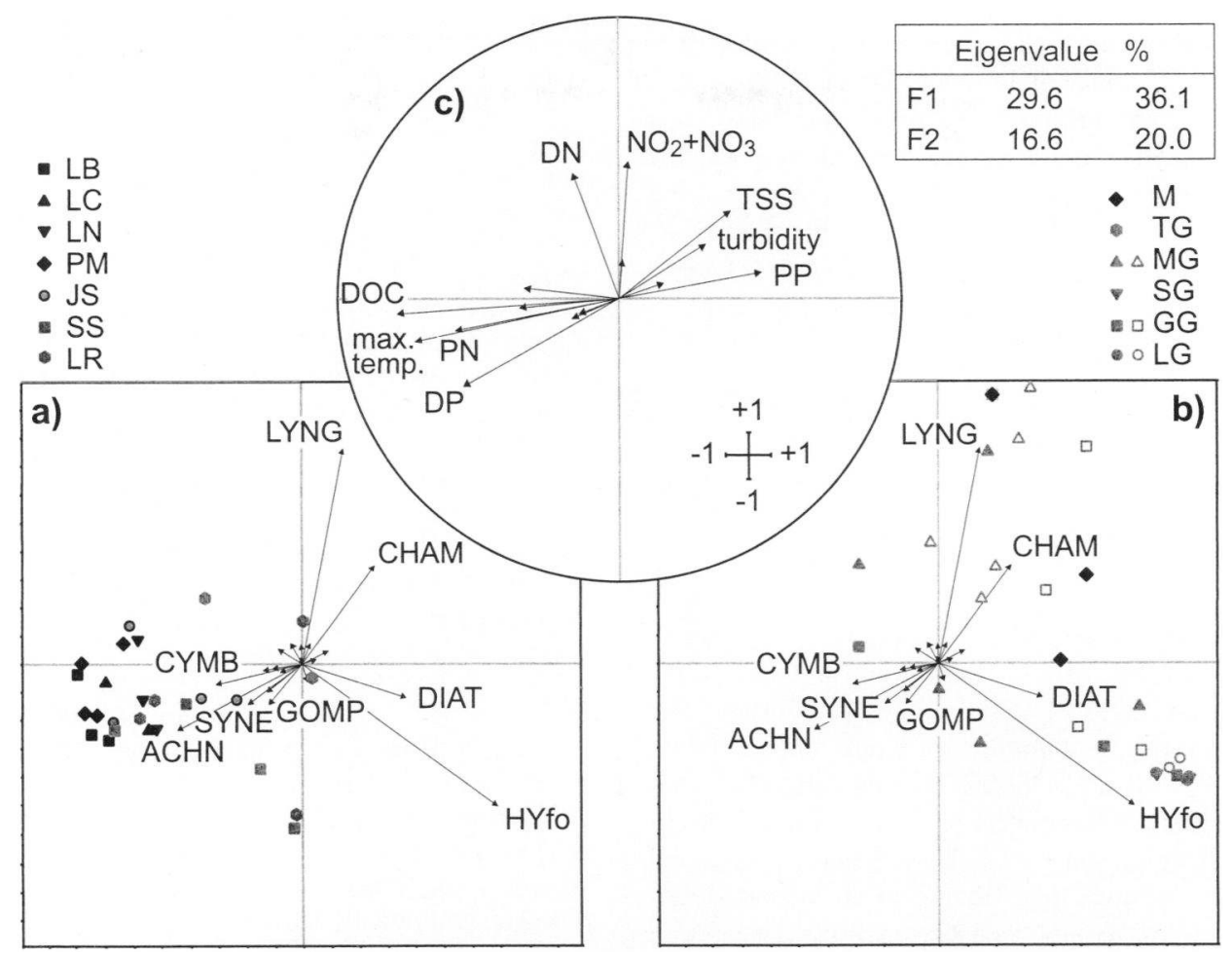

FIGURE 5. Principal components analysis ordination based on the frequency of the algal genera with a total frequency $>1 \%$ and the environmental data for each study site and date. a) and b) show the species-site ordination separated for a) all lake outlet sites and b) all stream sites. Symbols represent the different sampling sites (as defined in Table 1): black represents rhithral sites, gray represents kryal sites, and open gray symbols the respective kryal downstream sites. Arrows indicate algal taxa (notations as defined in Appendix 1). c) Ordination of the environmental data with arrows indicating the physicalchemical variables. Eigenvalues and percentage variance of species-environment relation (\%) are given for the first two axis $(F 1, F 2)$.

munities with large numbers of diatom taxa as well as Cyanophyta and Hydrurus foetidus, showing features of lake outlets and lowland streams.

\section{SEASONALITY IN ALGAL COMMUNITIES}

We observed little seasonality in community composition or genera richness, but found seasonal changes in abundances. Many studies of low- and midland streams showed a seasonal succession in algal community structure (see citations in Biggs, 1996). Corresponding to our findings, seasonality in algal communities was less pronounced in other studies of high-mountain coldwater streams (Kann, 1978; Maier, 1994; Kownacki et al., 1997; Passy et al., 1999; Vavilova and Lewis, 1999). In general, maximum numbers of green algae (e.g., Ulothrix zonata) were found in summer, blue-green algae in late summer and autumn, and Chrysophyceae (e.g., Hydrurus foetidus) during winter and spring. No distinct seasonal patterns were clear for the diatoms. At our sites, algae showed no seasonal succession in community composition but most genera had high abundances during autumn and winter, being most pronounced at kryal sites. The glacier influenced Joerisee outlet shifted from a rhithral lake outlet assemblage (Amphora perpusilla, Navicula spp., Nitzschia spp., and Synedra rumpens) during late summer and winter to one of a kryal site (lower richness, Hydrurus foetidus) during early summer (July 1998 and 1999) when the lake was affected by high discharge and turbidity from the Joeriglacier (Fig. 5).

\section{ENVIRONMENTAL VARIABLES AFFECTING ALGAL COMMUNITIES}

The predominant determinant of algal community structure in our study was the presence of a glacier. Glacial ice-melt results in strong seasonal fluctuations of flow and temperature that affects channel stability, turbidity (light), and nutrient availability (Milner and Petts, 1994). Temperature and light are major factors influencing seasonal changes in algal communities of other alpine systems (Kann, 1978; Kawecka, 1980). Besides solar intensity, light availability is restricted in kryal systems by high turbidity during summer and, in all systems, by snow cover in winter. Therefore, habitat conditions of kryal systems are most favorable for algae growth during early spring and late autumn (i.e., low flow and high light availability); which is consistent with our findings of algal abundances in kryal sites being highest during autumn and winter. Despite the limiting conditions of kryal systems, algal communities differed among our kryal streams, ranging from taxa-poor sites (e.g., Lang, Tschierva) to taxa-rich communities similar to those of rhithral sites (e.g., Morteratsch). We suggest that benthic algal characteristics may be dependent on the relative length of the favorable habitat conditions during spring and autumn among different kryal streams.

Our data support similar groupings of algal communities as those by Kawecka (1980) who analyzed 70 algal communities in alpine lotic systems of different European mountain ranges. The algal communities differed mainly among polluted and unpolluted streams, but among unpolluted sites algal communities also displayed characteristic structures of glacial streams, lake 
outlets, and alpine streams of different altitudinal zonation. Accordingly, in our study, another important determinant of benthic algal communities was the presence of an upstream lake. Lake outlets generally buffered temporal fluctuations in environmental parameters, thus leading to a more stable habitat throughout the year. Algal communities of the lake outlets reflected this stability, displaying communities without significant seasonal changes in richness or abundance.

\section{SUMMARY AND CONCLUSION}

Algal community composition of alpine streams and lake outlets were generally dominated by diatoms and blue-green algae. Although algal community composition tended to be similar among sites and many taxa occurred in all lotic systems, kryal sites generally were characterized by Hydrurus foetidus (Chrysophyceae) and Chamaesiphon spp. (Cyanophyta), whereas Oscillatoria spp., Phormidium spp. (Cyanophyta), and several diatom genera were indicative of lake outlet communities. The major factor governing the community structure among stream types was the presence of a glacier and the resulting effects on different physical-chemical parameters (e.g., temperature, turbidity, nutrients) and their seasonality. Lakes exerted a stabilizing effect on outlet communities, thus leading to an increased taxonomic richness with less pronounced seasonality.

\section{Acknowledgments}

Special thanks to Michael T. Monaghan in particular, and Andreas Blum, Peter Burgherr, and Marcos de la Puente for assistance in the field; Richard Illi and Bruno Ribi for completion of the chemical analysis in the laboratory; and Esther Keller and Regula Illi for additional identification of the benthic algae. We thank the communes of Pontresina, Samedan, and Klosters for providing access to the sites. We thank Ruben Sommaruga, Eugen Rott, and one anonymous reviewer for constructive comments that greatly improved the manuscript. The study was partially funded by a Swiss National Science Foundation Grant (no. 31-50440.97) examining the ecology of alpine lake outlets.

\section{References Cited}

Alger, A. S., McKnight, D. M., Spaulding, S. A., Tate, C. M., Shupe, G. H., Welch, K. A., Edwards, R., Andrews, E. D., and House, H. R., 1997: Ecological Processes in a Cold Desert Ecosystem: The Abundance and Species Distribution of Algal Mats in Glacial Meltwater Streams in Taylor Valley, Antarctica. University of Colorado at Boulder, Institute of Arctic and Alpine Research, Occasional Paper, 51. 108 pp.

Biggs, B. J. F., 1996: Patterns in benthic algae of streams. In Stevenson, R. J., Bothwell, M. L., and Lowe, R. L. (eds.), Algal Ecology. Thorp, J. H., Aquatic Ecology Series. San Diego: Academic Press, 31-56.

Biggs, B. J. F., Goring, D. G., and Nikora, V. I., 1998: Subsidy and stress responses of stream periphyton to gradients in water velocity as a function of community growth form. Journal of Phycology, 34: 589-607.

Brönmark, C. and Malmqvist, B., 1984: Spatial and temporal patterns of lake outlet benthos. Verhandlungen der Internationalen Vereinigung der Limnologie, 22: 1986-1991.

Brun, J., 1965: Diatomées des Alpes et du Jura. Amsterdam: A. Asher \& Co. 146 pp.

Cattaneo, A., Kerimian, T., Robegre, M., and Marty, J., 1997: Periphyton distribution and abundance on substrata of different size along a gradient of stream trophy. Hydrobiologia, 354: 101-110.

Chessman, B., Growns, I., Currey, J., and Plunkett-Cole, N.,
1999: Predicting diatom communities at the genus level for the rapid biological assessment of rivers. Freshwater Biology, 41: 317-331.

Elster, J. and Svoboda, J., 1996: Algal diversity, seasonality and abundance in, and along glacial stream in Sverdrup Pass, $79^{\circ} \mathrm{N}$, Central Ellesmere Island, Canada. Memoirs of National Institute of Polar Research, Special Issue, 51: 99-118.

Geitler, L., 1971: Cyanophyceae. XIV. New York, London: Johnson Reprint Corporation. 1196 pp.

Grimm, N. B. and Fisher, S. G., 1989: Stability of periphyton and macroinvertebrates to disturbance by flash floods in a desert stream. Journal of the North American Benthological Society, 8: 293-307.

Hill, B. H., Herlihy, A. T., Kaufmann, P. R., Stevenson, R. J., McCormick, F. H., and Johnson, C. B., 2000: Use of periphyton assemblage data as an index of biotic integrity. Journal of the North American Benthological Society, 19: 50-67.

Kann, E., 1978: Systematik und Ökologie der Algen österreichischer Berbäche. Archiv für Hydrobiologie/Supplementband, 53: 405-643.

Kawecka, B., 1965: Communities of benthic algae in the River Bialka and its Tatra tributaries the Rybi Potok and Roztoka. In Komitet Zagosp. Ziem Górskich PAN, Limnol. Invest. in the Tatra Mts and Dunajec River Basin. Zeszyt Nr. 11. Kraków: 113-127.

Kawecka, B., 1980: Sessile algae in European mountain streams, I. The ecological characteristics of communities. Acta Hydrobiologica, 22: 361-420.

Kawecka, B., 1981: Sessile algae in European mountain streams, 2. Taxonomy and autecology. Acta Hydrobiologica, 23: 1746.

Kownacki, A., Dumnicka, E., Galas, J., Kawecka, B., and Wojtan, K., 1997: Ecological characteristics of a high mountain lake-outlet stream (Tatra Mts. Poland). Archiv für Hydrobiologie, 139: 113-128.

Kuhn, D. L., Plafkin, J. L., Cairns, J., and Lowe, R. L., 1981: Qualitative characterization of aquatic environments using diatom life-form strategies. Transactions of the American Microscopical Society, 100: 165-182.

Maier, M., 1994: Die jahreszeitliche Veränderung der Kieselalgengemeinschaft in zwei geologisch unterschiedlichen Fliessgewässern der Alpen und ihre Verteilung auf verschiedenen Substraten. Diatom Research, 9: 121-131.

Malmqvist, B. and Brönmark, C., 1984: Functional aspects of a lake outlet versus a springfed stream ecosystem. Verhandlungen der Internationalen Vereinigung der Limnologie, 22: 1992-1996.

Milner, A. M. and Petts, G. E., 1994: Glacial rivers: physical habitat and ecology. Freshwater Biology, 32: 295-307.

Passy, S. I., Pan, Y., and Lowe, R. L., 1999: Ecology of the major periphytic diatom communities from the Mesta River, Bulgaria. International Review of Hydrobiology, 84: 129174.

Rott, E., Pipp, E., Pfister, P., van Dam, H., Ortler, K., Binder, N., and Pall, K., 1999: Indikationslisten für Aufwuchsalgen in österreichischen Fliessgewässern. Teil 2: Trophieindikation (sowie geochemische Präferenzen, taxonomische und toxikologische Anmerkungen). Wien: WWK, Bundesministerium für Land- und Forstwirtschaft, $248 \mathrm{pp}$.

Round, F. E., 1993: A Review and Methods for the Use of Epilithic Diatoms for Detecting and Monitoring Changes in River Water Quality 1993. Methods for the Examination of Waters and Associated Materials. London: HMSO. 65 pp.

Steneck, R. S. and Dethier, M. N., 1994: A functional group approach to the structure of algal-dominated communities. $\mathrm{Oi}$ kos, 69: 476-498.

ter Braak, C. J. F. and Smilauer, P., 1998: CANOCO Reference Manual and User's Guide to Canoco for Windows: Software for Canonical Community Ordination (version 4). Wageningen: Microcomputer Power, Ithaca, NY. 352 pp. 
Tockner, K., Malard, F., Burgherr, P., Robinson, C. T., Uehlinger, U., Zah, R., and Ward, J. V., 1997: Physico-chemical characterization of channel types in a glacial floodplain ecosystem (Val Roseg, Switzerland). Archiv für Hydrobiologie, 140: 433463.

Uehlinger, U., Zah, R., and Bürgi, H., 1998: The Val Roseg project: temporal and spatial patterns of benthic algae in an Alpine stream ecosystem influenced by glacier runoff. In Kovar, K., Tappeiner, U., Peters, N. E., and Craig, R. G. (eds.),
Hydrology, Water Resources and Ecology in Headwaters. Wallingford, UK: IAHS Publication, 248: 419-424.

Vavilova, V. V. and Lewis, W. M., 1999: Temporal and altitudinal variations in the attached algae of mountain streams in Colorado. Hydrobiologia, 390: 99-106.

Ward, J. V., 1994: Ecology of alpine streams. Freshwater Biology, 32: 277-294.

Zar, J. H., 1984: Biostatistical Analysis. Englewood Cliffs, N.J.: Prentice Hall. 718 pp. 


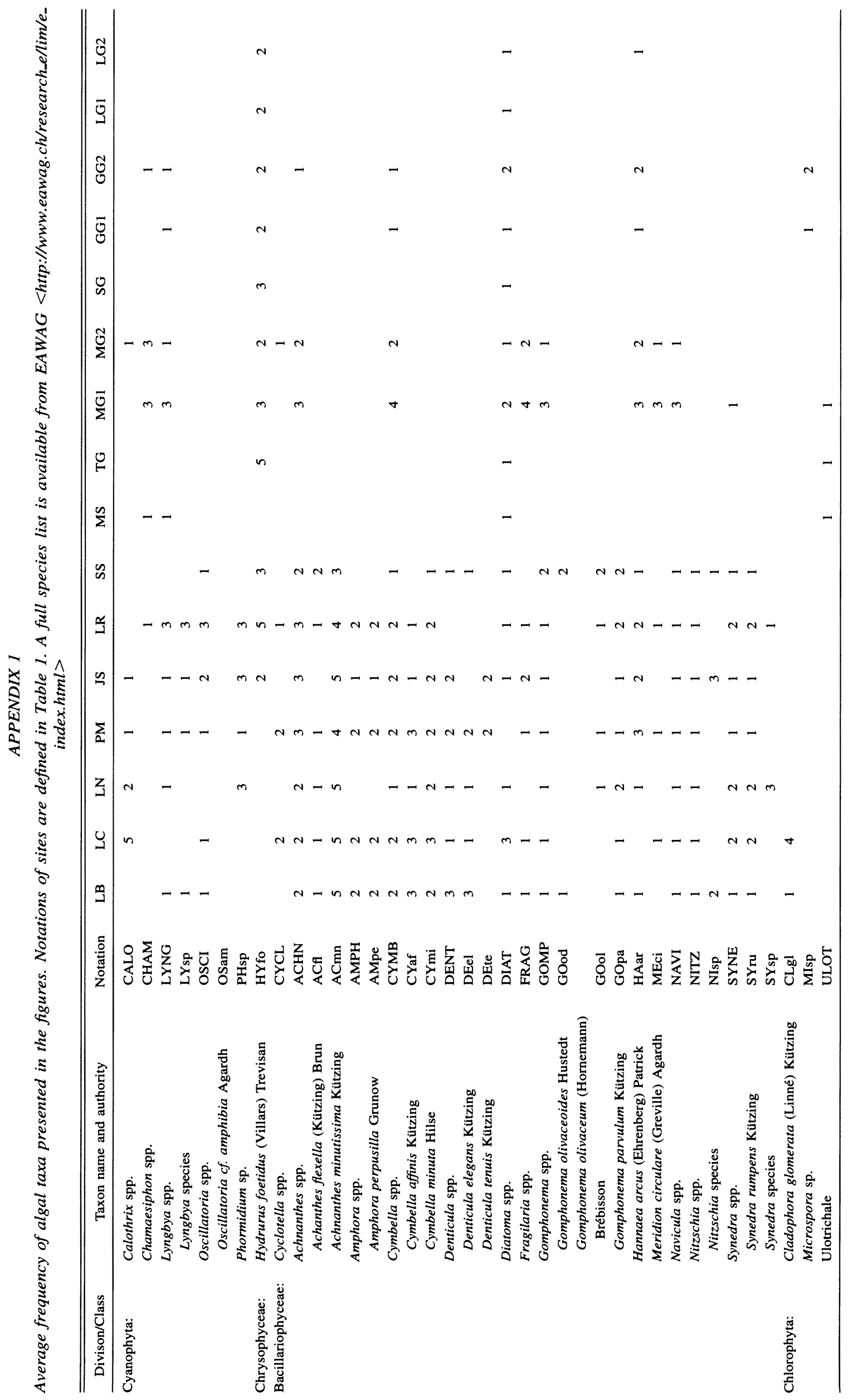

